\title{
Fucoidan inhibits vascular remodeling in transplant vasculopathy in rat
}

\section{Joanna Soin ${ }^{1,2}$, Ewa Kurzejamska ${ }^{1,3}$, Zbigniew Gaciong ${ }^{1}$, Gabriela Henrykowska ${ }^{2,5}$, and Krzysztof Bojakowski ${ }^{4}$}

${ }^{1}$ Department of Internal Medicine, Hypertension and Angiology, Medical University of Warsaw, Warsaw, Poland, '2State College of Applied Sciences in Skierniewice, Skierniewice, Poland; ${ }^{3}$ Department of Medicine, Centre for Molecular Medicine, Karolinska Institute, Stockholm, Sweden; ${ }^{4}$ Department of Immunology, Biochemistry and Nutrition, Medical University of Warsaw, Warsaw, Poland; ${ }^{5}$ Department of Epidemiology and Public Health, Medical University of Lodz, Lodz, Poland

Corresponding author: Joanna Soin, State College of Applied Sciences in Skierniewice, Skierniewice, Poland

Submission Date, March $21^{\text {st }}$, 2018, Acceptance Date, June $28^{\text {th }}, 2018$, Publication Date, June $30^{\text {th }}, 2018$

Citation: Soin J., Kurzejamska E., Gaciong Z., Henrykowska G., Bojakowski K., Fucoidan Inhibits Vascular Remodeling in Transplant Vasculopathy in Rat. Functional Foods in Health and Disease 2018; 8(6): 323-339. DOI: https://doi.org/10.31989/ffhd.v8i6.525

\footnotetext{
ABSTRACT

Background: Fucoidan is a natural sulfated polysaccharide which exists mainly in the cell wall matrix of various species of brown seaweed. Various forms of fucoidan have also been recognized in some marine invertebrates such as sea urchins and sea cucumbers.

Fucoidan inhibits the spread of cancerous cells by preventing the adhesion of tumor cells to the extracellular matrix in addition to inducing apoptosis, or programmed self-destruction, in human T-cells infected by T-cells leukemia virus type I (HTLV-1) which causes adult T-cell leukemia. The polysaccharide has also been shown to stimulate the phagocytic action of macrophages and synthesis of several immune cell types, which increases protection against infection. Fucoidan gives the immune system a big boost by enhancing phagocytosis. Additionally, it increases the number of mature white blood cells which are circulating in the body, thereby bolstering the first line of defense against infections and diseases. Fucoidan has anti-coagulant, anti-thrombotic, anti-inflammatory, antioxidant, anti-allergic, anti-tumor properties and also many others.

The aims of our study were to investigate the ability of fucoidan to alleviate vascular remodeling triggered by immunological stimuli in allogenic aorta transplantation within rats and to evaluate potential mechanisms of this action.
} 
Methods: In this study, we investigated whether fucoidan is able to alleviate the vascular remodeling process triggered by immunological stimuli in rat allogenic aorta transplantation model, in addition to the evaluated potential mechanisms responsible for the observed effects. Our rat aorta transplantation model was subjected to intraperitoneal or oral treatment with fucoidan or placebo.

Results: Our study demonstrated that fucoidan inhibits endointimal hyperplasia formation and vascular modulation. In particular, intraperitoneal and oral administration of fucoidan reduced neointima formation in allografts retrieved 8 weeks after transplantation. Moreover, both treatments with fucoidan reduced the number of smooth muscle (SM) $\alpha$-actin positive cells in intima and adventitia, decreased percentage of macrophages in intima and media, and increased the number of leukocytes in media of the allografts. Fucoidan treatments have also caused reduction in apoptosis in allograft intima and media.

Conclusion: Through our study, we demonstrated the inhibitory effect of fucoidan on vascular remodeling in transplant vasculopathy within rats. Our study is the first report of the beneficial effects of fucoidan oral administration on this process, which may have important clinical implications and result in a better understanding of vascular remodeling.

Keywords: fucoidan, transplant vasculopathy, vascular remodeling

\section{INTRODUCTION}

Intimal hyperplasia due to the smooth muscle cells (SMCs) and extracellular matrix accumulation is a key factor in the pathogenesis of transplant arteriosclerosis and restenosis after endovascular and vascular procedures [1,2]. Vascular remodeling in transplant arteriosclerosis involves inflammation of the vessel wall, SMCs apoptosis in the media, and SMCs proliferation in the intima, all of which result in the thickening of vascular wall and lumen narrowing [1].

Polysaccharides constitute a large family of molecules demonstrating the ability for numerous interactions with cellular targets within the arterial wall. Fucoidans are vegetal sulfated polysaccharides extracted from brown seaweed, which are reported to possess properties such as anti-coagulant, anti-thrombotic, anti-inflammatory, anti-tumor, anti-adhesive, and anti-viral activities [3, 4, 45, 46]. Many of these effects are mediated by fucoidan interactions with growth factors such as basic fibroblast growth factor [5] and the transforming growth factor-beta [6]. Other studies have described how fucoidan can induce the release of the glycosaminoglycan-bound stromal-derived factor-1 (SDF-1) from its tissue storage sites and influence progenitor cell mobilization [7-9, 42-44], which plays an important role in vascular remodeling. In several studies, fucoidan was reported to inhibit rat SMC proliferation in vitro more than heparin in airways [10] and in arteries $[11,12]$. Fucoidan or its homogeneous fractions have also been shown to inhibit instent restenosis within a rabbit model [13] and reduce intimal hyperplasia after balloon injury in rats [11], in addition to transplant vasculopathy after organ transplantation [14-16].

Fucoidan has an excellent oral safety profile in animals and humans [17]. Furthermore, fucoidan oral administration in human beings has been demonstrated to be clinically valuable. Oral administration in humans significantly increases the number of CD34 (+) cells in the peripheral 
blood, proportion of CD34 (+) cells which expressed CXCR4, plasma level of SDF-1, and IFNgamma level [18]. Recently, oral administration has been investigated in a clinical phase I and II study for the treatment of osteoarthritis [19].

\section{MATERIALS AND METHODS}

\section{Reagents}

Fucoidan was extracted from seaweed Fucus vesiculosus (Sigma, St. Louis, Mo, USA). Monoclonal antibodies to SM alpha-actin were obtained from Sigma (St. Louis, MO). Monoclonals to SM myosin were obtained from Santa Cruz Biotechnology (Santa Cruz, CA). Monoclonals to ED1 from Serotec (Raleigh, NC), and polyclonals to CD45 and monoclonals to OX22 were obtained from Transduction Laboratories (Lexington, KY). The Vectastain Elite ABC kit, 3, 3-diaminobenzidine (DAB), normal rat serum, normal goat serum, biotinylated anti-goat antibodies, biotinylated anti-mouse antibodies, normal rabbit immunoglobulins, and normal mouse immunoglobulins were obtained from Vector Laboratories (Burlingame, CA). Normal rat serum was provided by Dako (Glostrup, Denmark). The primary antibodies used for the immunostainings are presented in Table 1.

Table 1. Primary antibodies used in the study

Epitope Marker $\quad$ Dilution Source

SM $\alpha$-actin

SMCs,

$1: 200$

Sigma (St. Louis, MO)

myofibroblasts

CD45

Leukocytes

$1: 20$

Transduction

Laboratories

(Lexington, KY)

ED-1

Macrophages

$1: 100$

Serotec (Raleigh, NC)

\section{Transplantation procedure}

Inbred rats (225-275 g) of the F334.RT1v1, LEW.RT1, SHR, and WKY strains were used and treated according to institutional guidelines (experimental protocols were approved by the local ethical committee). Anesthesia was performed with fentanyl/fluanisone plus diazepam $(0.6 \mathrm{~mL} / \mathrm{kg}$ and $2.5 \mathrm{mg} / \mathrm{kg}$ respectively, administered intraperitoneally). Abdominal aortic segments of F334.RT1v1 male rats were orthotopically transplanted to LEW.RT1 male rats [20]. Similarly, aortas retrieved from SHR rats were transplanted to WKY rats. The grafts were procured after 1, 2, 3, 4, 6, and 8 weeks. Isogenic aorta transplantations of Lewis or WKY rats served as controls.

We used two different combinations of rat allogenic aorta transplantation to avoid strain specific effects of fucoidan. As fucoidan can influence blood pressure [21], we tested this possibility by using the SHR/WKY combination. Additionally, we measured blood pressure in rats 8 weeks after transplantation. However, we did not notice any influence of fucoidan (data not 
shown). After aorta transplantation, animals were randomized into placebo or fucoidanadministered groups. SHR $\rightarrow$ WKY transplants received intraperitoneal injection of saline (placebo group) twice daily or $0.4 \mathrm{mg} / \mathrm{kg}$ BID fucoidan. In experiments with oral administration of fucoidan, F344 $\rightarrow$ Lewis transplants were given water solutions of fucoidan $(1,10$, and $100 \mathrm{mg} / \mathrm{L})$ or drinking water ad libitum (placebo group). Each experimental group consisted of 6-8 rats. Rats were housed individually after transplantation. All of the animal research was conducted in accordance with the Declaration of Helsinki and procedures were performed according to international guidelines.

\section{Sample collection}

The specimens of transplanted aortas were washed with $0.9 \% \mathrm{NaCl}$ and divided into two parts. The first part was prepared for histopathological and immunohistochemical examinations. The second part of the specimens was snap-frozen in liquid nitrogen for RT-PCR analysis.

\section{Morphological analysis}

For light microscopy, standard procedure was performed. Namely, 5- $\mu \mathrm{m}$ thick sections were cut using standard microtome, routinely stained with SM $\alpha$-actin, and studied in a Nikon Labophot microscope (Nikon, Tokyo, Japan). For morphometric analysis, photographs of vessels crosssections were prepared at a final magnification of $100 \mathrm{x}$ and measured with Lucia 3.5 software (Lucia, Prague, Czech Republic).

\section{Immunohistochemistry}

Serial transverse sections $\left(10 \mu \mathrm{m}\right.$ thick) were cut using a cryostat at $-20^{\circ} \mathrm{C}$. Sections were stained with SM $\alpha$-actin to investigate the histopathological changes. The transverse sections were incubated with appropriate dilutions of primary antibody overnight at $+4^{\circ} \mathrm{C}$. After being washed with TRIS-buffered saline (TBS, pH7.5), bound primary antibodies were visualized by avidinbiotin peroxidase kits (Vector Laboratories, Burlingame, Calif., USA) against mouse Ig (Vectastain PK-4002) or rabbit Ig (Vectastain PK-4001) using DAB (Sigma) as a chromogen. The sections were then counterstained with hematoxylin.

\section{In situ TUNEL assay}

In situ TUNEL (TdT-mediated dUTP Nick-End Labeling) assays were performed using a kit from Boehringer Mannheim (Mannheim, Germany) according to the manufacturer's instructions. Briefly, sections were rehydrated, digested with proteinase $\mathrm{K}(20 \mu \mathrm{g} / \mathrm{mL})$ for 30 minutes, washed in PBS, and then incubated with td-transferase and biotin-labeled nucleotide mixture for 30 minutes at $37^{\circ} \mathrm{C}$.

\section{Data presentation}

Positive cellular and nuclear staining for SM $\alpha$-actin, ED-1, CD45, and TUNEL were estimated by counting positive cells in light microscopy images. All cells present in the intima and media 
were counted from one representative section from each animal. SM $\alpha$-actin staining was estimated according to a 4-point-scale ( 0 - no positive staining; 1 - few positive cells; 2 - many positive cells; 3 - all cells positive).

\section{Statistics}

All results are presented as the means \pm SD. Comparisons between two groups were performed using t-Student test, while multivariate comparisons were performed using ANOVA with post hoc comparisons by Scheff's test.

\section{RESULTS}

\section{Fucoidan inhibits formation of the endointimal hyperplasia and vascular modulation}

Fucoidan administered every 12 hours intraperitoneally at a dose of $0.4 \mathrm{mg} / \mathrm{kg}$ BID significantly inhibited neointima formation in allografts retrieved 8 weeks after transplantation (Table 2). Mean intima width in fucoidan group was significantly reduced compared to the control group $(5.2 \pm 1.5$ $\mu \mathrm{m}$ vs. $58.1 \pm 4.4 \mu \mathrm{m}$ respectively $\mathrm{p}<0.0001)$. Intimal area in fucoidan group was significantly reduced compared to the controls $\left(8.3 \pm 3.0\right.$ vs. $157.3 \pm 12.310^{2} \mu \mathrm{m}$ respectively, $\left.\mathrm{p}<0.0001\right)$. Significantly, fucoidan treatment conducted at the same time led to an increase in medial layer width compared to the controls $(77.3 \pm 3.9$ vs. $72.8 \pm 3.1, \mathrm{p}=0.0228)$. However, no medial area was affected.

Table 2. Effect of intraperitoneal administration of fucoidan on vascular remodeling in 8 week allografts.

\begin{tabular}{|c|c|c|c|}
\hline \multirow[b]{2}{*}{ Group } & \multirow{2}{*}{$\begin{array}{c}\text { syngenic } \\
(\mathrm{WKY} \rightarrow \mathrm{WKY}) \\
(\mathrm{n}=6)\end{array}$} & \multicolumn{2}{|c|}{ allogenic $(\mathrm{SHR} \rightarrow \mathrm{WKY})$} \\
\hline & & $\begin{array}{c}\mathbf{0 , 9 \%} \mathrm{NaCl} \\
(\mathbf{n}=10)\end{array}$ & $\begin{array}{c}\text { fucoidan } 2 \times 0.4 \mathrm{mg} / \mathrm{kg} \mathrm{m.c} \\
\text { i.p. }(\mathrm{n}=6)\end{array}$ \\
\hline $\begin{array}{c}\text { Intimal layer width } \\
(\mu \mathrm{m})\end{array}$ & $3.5 \pm 2.9$ & $58.1 \pm 4.4^{\#}$ & $5.2 \pm 1.5^{\ddagger}$ \\
\hline $\begin{array}{c}\text { Intimal layer area } \\
\left(\mu \mathrm{m} \times 10^{2}\right)\end{array}$ & $4.9 \pm 3.1$ & $157.3 \pm 12.3^{\#}$ & $8.3 \pm 3.0^{\ddagger}$ \\
\hline $\begin{array}{c}\text { Medial layer width } \\
(\mu \mathrm{m})\end{array}$ & $80.2 \pm 3.0$ & $72.8 \pm 3.1$ & $77.3 \pm 3.9 *$ \\
\hline $\begin{array}{l}\text { Medial layer area } \\
\quad\left(\mu \mathrm{m} \times 1^{2}\right)\end{array}$ & $235.5 \pm 8.3$ & $228.6 \pm 9.2$ & $221.0 \pm 6.4$ \\
\hline
\end{tabular}

Results are shown as mean $\pm \mathrm{SD} ;{ }^{\#} \mathrm{p}<0,05$ in comparison to syngenic, ${ }^{\ddagger} \mathrm{p}<0,05$ in comparison to allogenic (down), * $\mathrm{p}<0,05$ in comparison to allogenic (up). 
Additionally, oral administration of fucoidan resulted in reduction of neointima formation in allogenic transplants (Table 3). Rats treated with fucoidan water solutions at doses of $1 \mathrm{mg} / \mathrm{L}$ and $10 \mathrm{mg} / \mathrm{L}$ had significantly smaller intima widths than controls $(29.7 \pm 3.3,34.3 \pm 7.1 \mu \mathrm{m}$ vs. $60.2 \pm 5.9$ $\mu \mathrm{m}$ respectively, $\mathrm{p}<0.0001$ in both cases). Similarly, intimal areas in mouse groups treated with fucoidan at doses of 1 and $10 \mathrm{mg} / \mathrm{L}$ were significantly reduced in comparison to control group (135.1 $\pm 25.9,78.7 \pm 26.510^{2} \mu \mathrm{m}$ vs. $269.9 \pm 41.610^{2} \mu \mathrm{m}$, respectively, $\mathrm{p}<0.0001$ in both cases). Surprisingly, neointima formation was not reduced by highest oral doses of fucoidan. In this group both intima width and intimal area were higher when compared to the values determined in control group ( $88.3 \pm 15.5$ vs. $60.2 \pm 5.9, \mathrm{p}=0.002 ; 372.8 \pm 51.1$ vs. $269.9 \pm 41.6, \mathrm{p}=0.003)$.

Table 3. Effect of oral administration of fucoidan on vascular remodeling in 8 -week allografts.

\begin{tabular}{|c|c|c|c|c|c|}
\hline \multirow[b]{2}{*}{ Group } & \multirow{2}{*}{$\begin{array}{c}\text { syngenic } \\
\left(\begin{array}{c}\text { F344 } \rightarrow \text { F3 } \\
\text { 44) } \\
(n=6)\end{array}\right.\end{array}$} & \multicolumn{4}{|c|}{ allogenic $($ F344 $\rightarrow$ Lewis $)$} \\
\hline & & $\begin{array}{c}\text { control } \\
(n=6)\end{array}$ & $\begin{array}{c}\text { fucoidan } 1 \\
\text { mg/L } \\
(\mathbf{n}=6)\end{array}$ & $\begin{array}{c}\text { fucoidan } 10 \\
\text { mg/L } \\
(n=6)\end{array}$ & $\begin{array}{c}\text { fucoidan } 100 \\
\text { mg/L } \\
(n=6)\end{array}$ \\
\hline $\begin{array}{c}\text { Intimal layer width } \\
(\mu \mathrm{m})\end{array}$ & $3.2 \pm 2.1$ & $60.2 \pm 5.9$ & $29.7 \pm 3.3^{\#}$ & $34.3 \pm 7.1^{\#}$ & $88.3 \pm 15.5^{\ddagger}, \S^{*}$ \\
\hline $\begin{array}{l}\text { Intimal layer area } \\
\qquad\left(\mu \mathrm{m} \times 10^{2}\right)\end{array}$ & $5.1 \pm 4.5$ & $269.9 \pm 41.6$ & $135.1 \pm 25.9^{\#}$ & $78.7 \pm 26.5^{\#}$ & $372.8 \pm 51.1$ औ,,$*$ \\
\hline $\begin{array}{c}\text { Medial layer width } \\
(\mu \mathrm{m})\end{array}$ & $99.5 \pm 4.0$ & $55.5 \pm 5.8$ & $81.3 \pm 3.8 *$ & $81.9 \pm 8.4 *$ & $59.9 \pm 4.4$ \\
\hline $\begin{array}{l}\text { Medial layer area } \\
\qquad\left(\mu \mathrm{m} \times 1^{2}\right)\end{array}$ & $380.2 \pm 21.4$ & $246.5 \pm 18.7$ & $337.1 \pm 15.1 *$ & $300.8 \pm 26.2 *$ & $282.0 \pm 70.6$ \\
\hline
\end{tabular}

Results are shown as mean \pm SD. ${ }^{*} \mathrm{p}<0.05$ in comparison to control (down), $* \mathrm{p}<0.05$ in comparison to control (up) $\$, \mathrm{p}<0.05$ in comparison to fucoidan $1 \mathrm{mg} / \mathrm{L},{ }^{\S} \mathrm{p}<0.05$ in comparison to fucoidan $10 \mathrm{mg} / \mathrm{L}$.

Moreover, fucoidan administered orally increased both medial width (fucoidan $1 \mathrm{mg} / \mathrm{L}$ $81.3 \pm 3.8$ vs. $55.5 \pm 5.8, \mathrm{p}<0.0001$; fucoidan $10 \mathrm{mg} / \mathrm{L} 81.9 \pm 8.4$ vs $55.5 \pm 5.8, \mathrm{p}<0.0001)$ and area (fucoidan $1 \mathrm{mg} / \mathrm{L} 337.1 \pm 15.1$ vs. $246.5 \pm 18.7$, p $<0.0001$; fucoidan $10 \mathrm{mg} / \mathrm{L} 300.8 \pm 26.2$ vs. $246.5 \pm 18.7, \mathrm{p}=0.002)$. 


\section{Fucoidan changes cellular composition of the vessels}

Fucoidan administered orally significantly reduced a number of $\alpha$-actin positive cells in intima of 8 weeks allogenic arteries $(0.20 \pm 0.45$ vs. $1.75 \pm 0.96, p=0.039)$ was observed (Fig.1).

Figure 1. Effect of oral and intraperitoneal administration of fucoidan on a number of $\alpha$-actin positive cells in vascular wall in 2 (A and $\mathrm{C}$ ) and 8 (B and D) weeks allografts in comparison to control group.

\section{A}

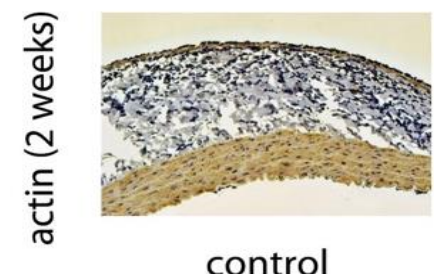

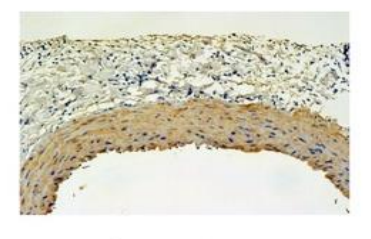

fucoidan $2 \times 0.4 \mathrm{mg} / \mathrm{kg}$ BID i.p.

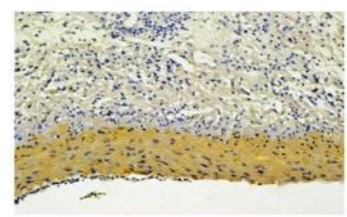

fucoidan $10 \mathrm{mg} / \mathrm{l}$ p.o.

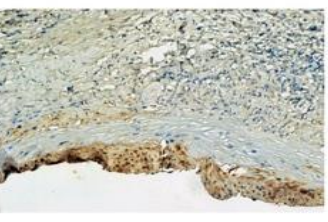

fucoidan

fucoidan $2 \times 0.4 \mathrm{mg} / \mathrm{kg}$ BID i.p.
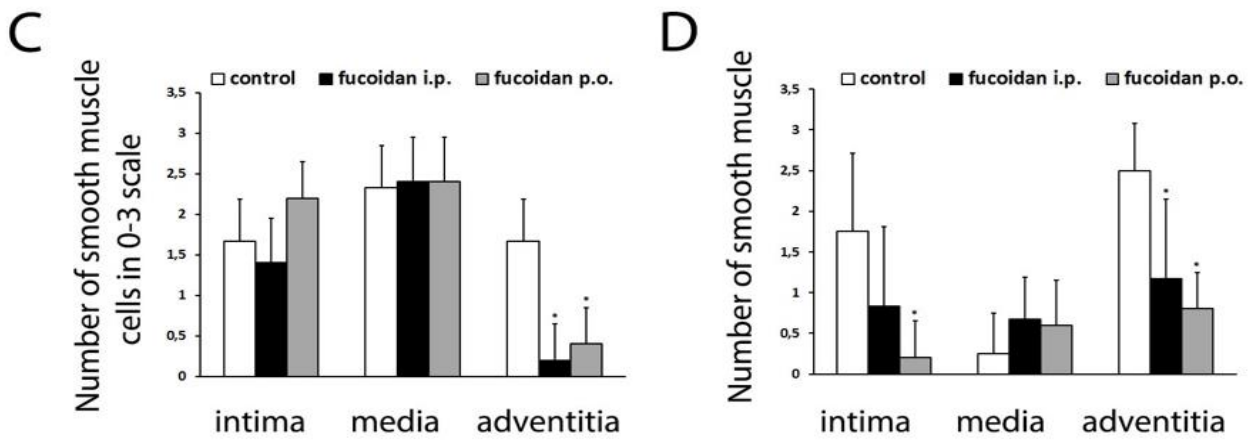

Results are shown as mean $\pm \mathrm{SD} . * \mathrm{p}<0.05$ in comparison to control group.

Even though administration of fucoidan did not have significant influence on a number of $\alpha$ actin positive cells present in medial layer, fucoidan affected these cells in adventitia. In particular, fucoidan that was given intraperitoneally significantly reduced number of $\alpha$-actin positive cells in adventitia of 2 and 8 weeks allografts $(0.20 \pm 0.45$ vs. $1.67 \pm 0.52, p=0.001$ and $1.17 \pm 0.98$ vs. $2.50 \pm 0.58, \mathrm{p}=0.027)$. Similarly, oral administration of fucoidan $(10 \mathrm{mg} / \mathrm{L})$ diminished number of $\alpha$-actin positive cells in adventitia of 2 and 8 weeks in comparison to control group $(0.40 \pm 0.45$ vs. $1.67 \pm 0.52, \mathrm{p}=0.022$ and $0.80 \pm 0.45$ vs. $2.50 \pm 0.58, \mathrm{p}=0.003$ ). 


\section{Fucoidan modulates inflammation in the vessels}

Fucoidan was administered in two ways -intraperitoneally and orally. Both methods significantly decreased percentage of macrophages (ED-1 positive cells) in intima and media of 8 weeks allografts compared to the control group (in i.p. group $-3.3 \pm 2.5$ vs. $10.3 \pm 2.2, \mathrm{p}=0.002$ in intima, $10.0 \pm 2.8$ vs. $33.0 \pm 5.7, \mathrm{p}=0.001$ in media; in p.o. group $-6.2 \pm 2.0$ vs. $10.3 \pm 2.2, \mathrm{p}=0.001$ in intima, $12.4 \pm 2.1$ vs. $33.0 \pm 5.7, \mathrm{p}=0.003$ in media) (Fig. 2). In allografts 8 weeks after transplantation, macrophages (ED-1 positive cells) accounted for nearly $1 / 3$ of all detected cells in media (fucoidan reduced this number to $10-14 \%$ ).

Moreover, only fucoidan administered intraperitoneally reduced the number of macrophages detected in adventitia of 2 -weeks allografts compared to the control group $(4.4 \pm 1.7$ vs. $8.3 \pm 2.9$, $\mathrm{p}=0.024)$, while no effect of fucoidan administered orally on number of macrophages in adventitia was observed.

Figure 2. Effect of oral and intraperitoneal administration of fucoidan on number of macrophages (ED-1 positive cells) in vascular wall in 2 ( $\mathrm{A}$ and $\mathrm{C}$ ) and 8 (B and D) weeks allografts in comparison to control group.
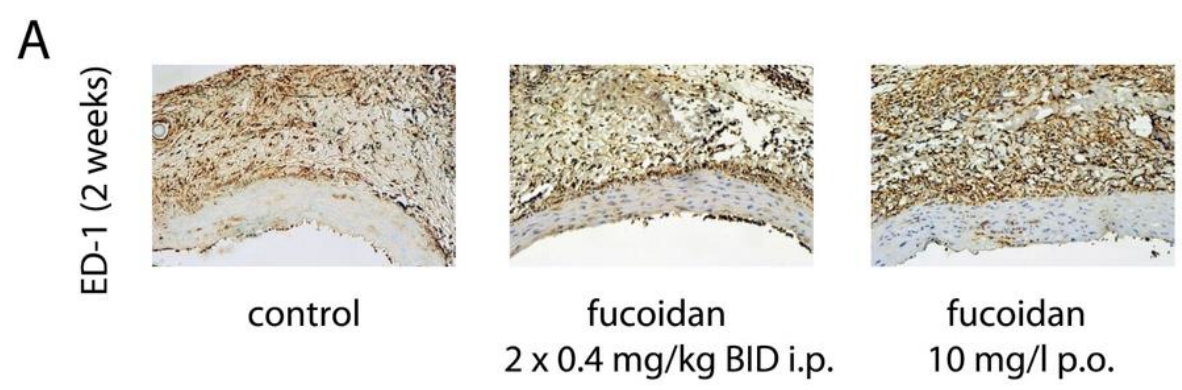

B
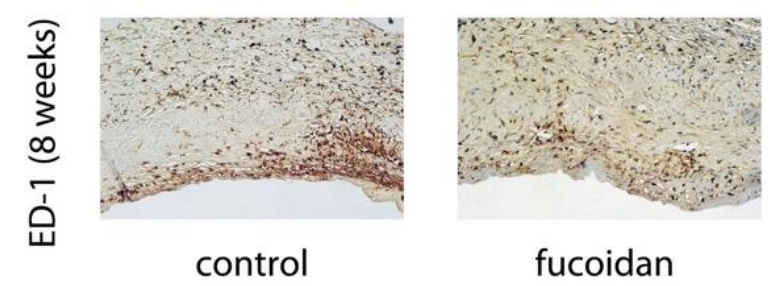

fucoidan

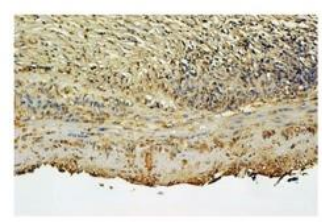

$2 \times 0.4 \mathrm{mg} / \mathrm{kg}$ BID i.p. fucoidan

$10 \mathrm{mg} / \mathrm{l} \mathrm{p.o.}$
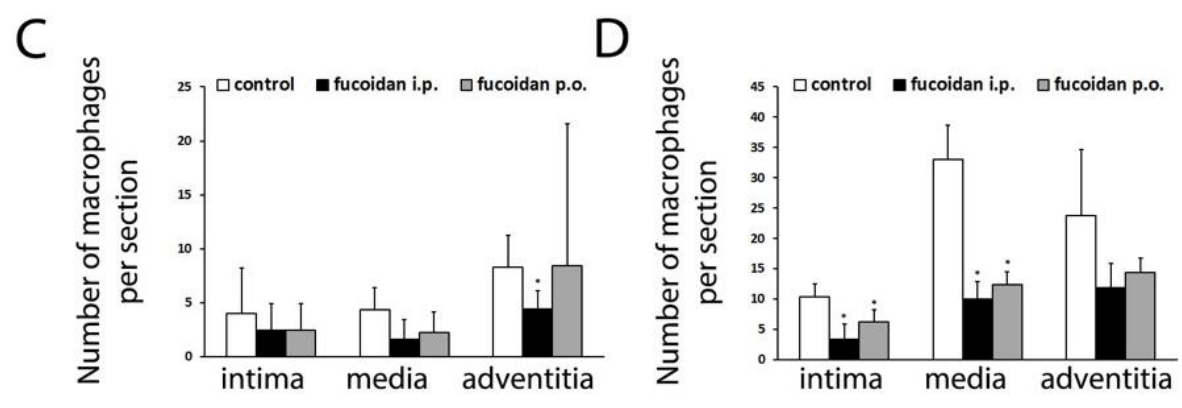

Results are shown as mean \pm SD. $* \mathrm{p}<0.05$ in comparison to control group. 


\section{Fucoidan affects number of leukocytes in the vessels}

Both oral and intraperitoneal administration of fucoidan increased number of leukocytes stained with anti-CD45 antibody in the media of 8 -weeks allografts (3.5 \pm 1.4 in i.p. group, $2.8 \pm 0.8$ in p.o. group vs.0.3 \pm 0.5 in control group, $\mathrm{p}=0.001$ and $\mathrm{p}<0.0001$ respectively) (Fig. 3). Additionally, the oral administration of fucoidan caused an increase in number of CD45-positive cells in adventitia of 2-week allografts. Surprisingly, both treatments contributed also to CD45 decrease in the intima of 2-week allografts $(0.2 \pm 0.4$ in i.p. group, $0.8 \pm 0.4$ in p.o. group vs. $2.7 \pm 1.6, p=0.01$ and $p=0.04$, respectively).

Figure 3. Effect of oral and intraperitoneal administration of fucoidan on number of leukocytes (CD45 positive cells) in vascular wall in 2 (A and C) and 8 (B and D) weeks allografts in comparison to control group.

A

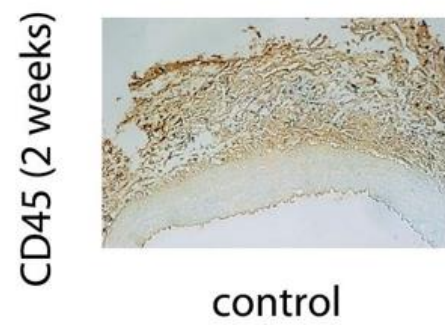

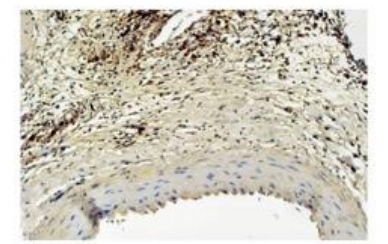

fucoidan

$2 \times 0.4 \mathrm{mg} / \mathrm{kg}$ BID i.p.

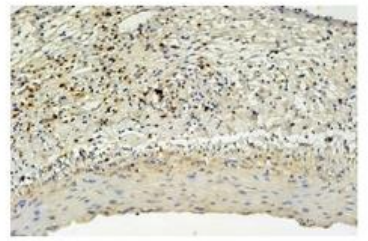

fucoidan

$10 \mathrm{mg} / \mathrm{l} \mathrm{p.o.}$

B

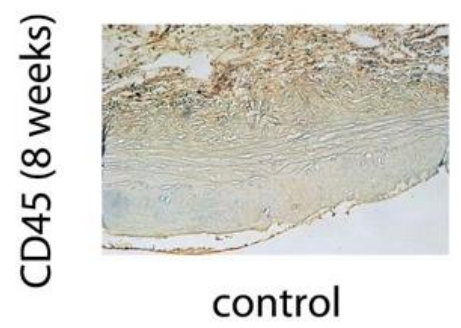

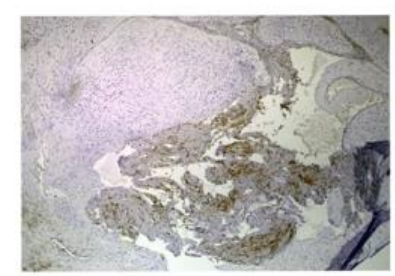

fucoidan

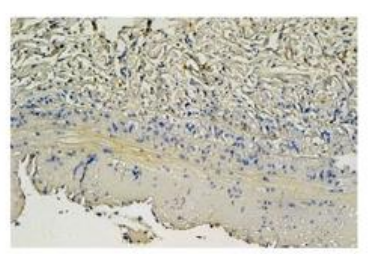

fucoidan

\section{$2 \times 0.4 \mathrm{mg} / \mathrm{kg}$ BID i.p. $\quad 10 \mathrm{mg} / \mathrm{l}$ p.o.}
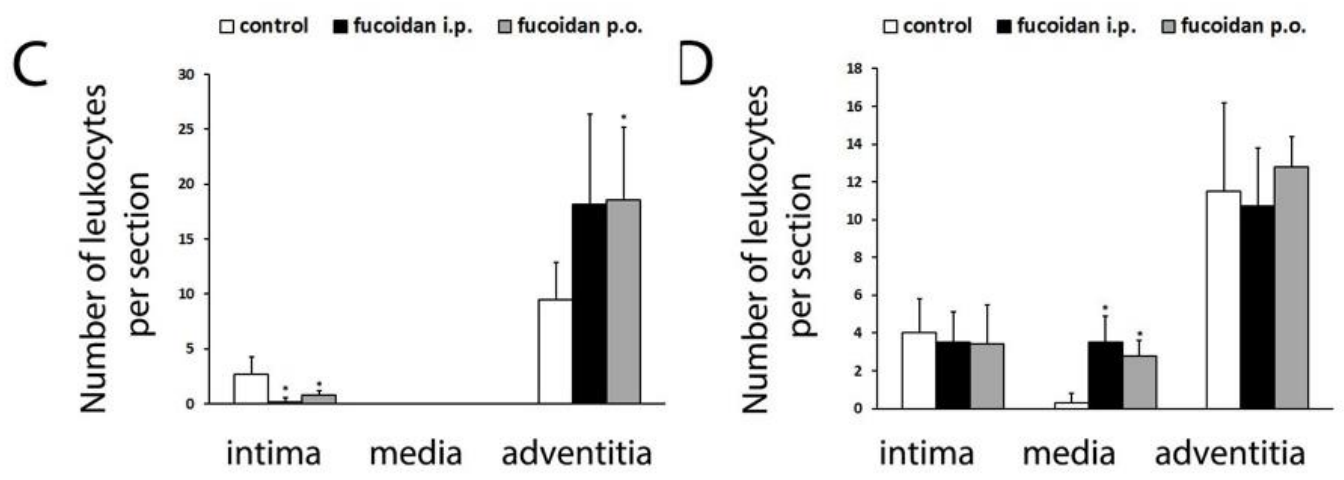

Results are shown as mean $\pm \mathrm{SD}$. ${ }^{*} \mathrm{p}<0.05$ in comparison to control group. 


\section{Fucoidan reduces apoptosis in the vessel wall}

Both oral and intraperitoneal fucoidan administration reduced the number of apoptotic cells in medial layer in 2-week allografts $(4.8 \pm 1.8$ vs. $9.3 \pm 2.4, \mathrm{p}=0.006$ in i.p. treatment, $3.8 \pm 1.3$ vs. $9.3 \pm 2.4, p=0.001$ in p.o. treatment) (Fig. 4 )

Figure 4. Effect of oral and intraperitoneal administration of fucoidan on number of apoptotic cells in vascular wall in 2 (A and C) and 8 (B and D) weeks allografts in comparison to control group.

A
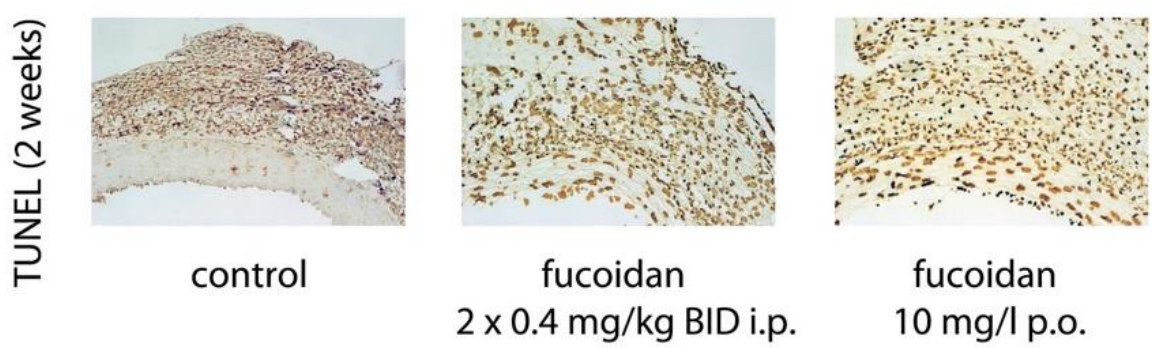

B
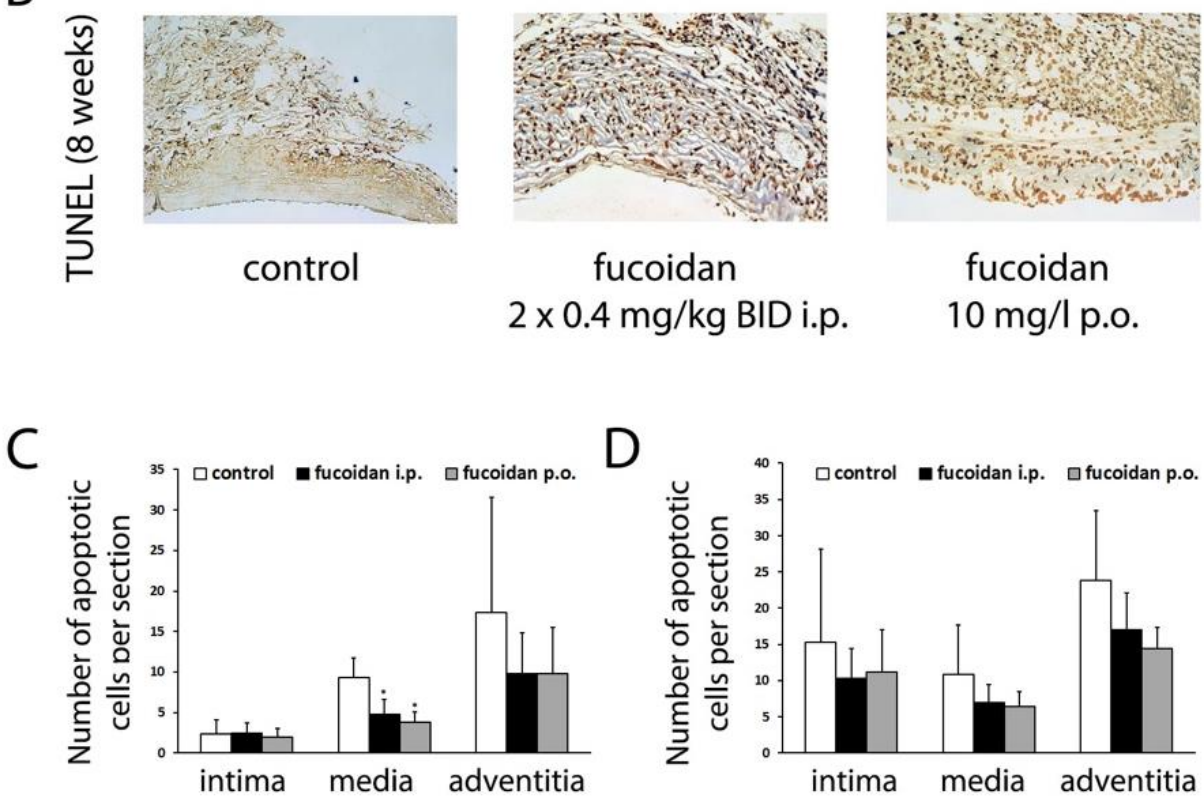

Results are shown as mean $\pm \mathrm{SD}$. ${ }^{*} \mathrm{p}<0.05$ in comparison to control group.

\section{DISCUSSION}

In our experiment we observed the attenuation of vascular remodeling by the oral and intraperitoneal administration of fucoidan. In previous studies, fucoidan administered intraperitoneally was effective in the inhibition of vascular remodeling, characterized by the intimal proliferation and increased number of SMCs in intima, induced by mechanical stimuli in rats [11] and rabbits [13]. Moreover, the low molecular weight (LMW) fucoidan was effective in preventing transplant vasculopathy in hearts and aorta transplantation in rats $[14,15]$. 
Fucoidan decreased the number of myocytes/myofibroblasts in the intimal layer of allografts. Many observations from animal models and clinical studies demonstrated the important role of myocytes proliferation and migration in vascular remodeling and intimal growth [22]. In our study, fucoidan administration led to the coincidence of reduction in intimal layer growth and number of smooth-muscle cells in intima in allografts. This reduction may be related to the inhibition of myocytes/myofibroblasts migration from media and adventitia to intimal layer, caused by the inhibition of extracellular matrix degradation, especially fibers of internal elastic membrane. Fucoidan locally modulates the expression of matrix metalloproteases, thereby influencing matrix components degradation [23]. The decrease of the number of SMCs in the intimal layer may be also caused by antiproliferative activity of fucoidan, which was well documented within in vitro studies [24, 25]. Inhibition of smooth muscle cells proliferation by fucoidan is mediated by modification of growth factors and cytokines action, which can potentially exert antiproliferative activity and induce differentiation to contractile phenotype. In our study, fucoidan administration also reduced the number of $\alpha$-actin positive cells (most likely myofibroblasts) in the adventitial layer. This reduction fucoidan inhibits fibroblast activation and/or their differentiation into myofibroblasts-the other potential source of cells in the intimal layer [26]. Inhibition of fibroblasts differentiation to myofibroblasts by heparin was previously demonstrated to be mediated by heparin interaction with cytokines and their receptors [27]. Moreover, previous studies revealed that non-anticoagulant heparins can inhibit rat smooth muscle cell adhesion and proliferation [28].

Our study also demonstrated how both types of fucoidan treatments not only inhibit neointima formation but also increases medial width and area. This effect can be explained by different mechanisms, including increased media hyperplasia, hypertrophy, remodeling of extracellular matrix, or inflammatory edema. We observed that fucoidan treatment also resulted in higher numbers of leukocytes in the media, which may also contribute to the increased size of media. This finding is particularly significant as leukocyte migration to injured endothelium is known to incite a proinflammatory endothelial phenotype which can potentially contribute to early neointimal hyperplasia $[29,30]$. However, fucoidan has not been previously proven to increase leukocyte recruitment. Furthermore, it was reported to inhibit leukocyte recruitment in a model of peritoneal inflammation [31]. Therefore, the increased media size of allografts in addition to the higher number of leukocytes may not be due to fucoidan treatment itself and may instead be caused by allogenic media injury as a result of transplantation.

Our results have demonstrated that fucoidan, in early stages of vascular remodeling, alleviated apoptosis of medial layer cells, mainly with smooth muscle cells. However, SMCs apoptosis observed in transplant vasculopathy coincided with the strong effect of fucoidan on SMCs proliferation may cause reduction of these cell numbers in the medial layer [11, 12].

Paradoxically, fucoidan at higher doses enhances vascular remodeling. As we did not observe differences in fucoidan oral consumption, this enhancement can be explained by mechanisms which are absent or inhibited by lower doses of fucoidan. Recent studies examining SMCs origin reveal four potential sources of SMCs, including the migration of medial SMCs, proliferation of pre-existing intimal clones, migration of adventitial fibroblasts, and infiltration of circulating progenitor cells [16]. Several lines of evidence suggest that SDF-1 $\alpha$ is a key molecule regulating hematopoietic progenitor cell mobilization, with its blockade preventing recruitment of circulating SMC progenitor cells into neointimal lesions induced by vascular injury [16]. Overexpression of 
SDF- $1 \alpha$ and its receptor CXCR4 coincides with the exacerbation of neointimal lesion formation and in animal models of transplant vasculopathy [32]. Fucoidan can release the glycosaminoglycan-bound stromal-derived factor-1 (SDF-1) from its tissue storage sites [7-9]. The effect on SDF and progenitor SMCs mobilization is one of potential mechanisms of neointimal progression by high fucoidan doses.

Our data documents a decrease in the number of macrophages in the vascular wall following fucoidan administration. The recruitment, activation, and proliferation of monocytes/macrophages in the vessel wall may contribute to the process of atherosclerosis and restenosis. The presence of activated monocytes/macrophages at the site of the vascular injury leads to the release of vasoactive molecules, cytokines, chemokines, and growth factors which can induce the migration and proliferation of SMCs $[16,33,46]$. Macrophages present in atherosclerotic plaque causes instability and increases the incidence of acute ischemic episodes [34]. The reduction of the number of macrophages in the vascular wall by fucoidan may be caused by its direct effect on macrophages migration or influence on extracellular matrix degradation. Fucoidan has been shown to be a ligand of the macrophage scavenger receptor (MSR) [35] that effectively competes with OxLDL for binding to MSR, a process which can inhibit transformation of macrophages to foam cells [36]. Moreover, fucoidan inhibits MSR-mediated adhesion of macrophages to extracellular matrix of atherosclerotic plaques and endothelial cells [37]. Fucoidan blocks neutrophil-derived heparin-binding-protein (HBP) interaction with monocytes. HBP has a variety of physiological regulatory effects for monocytes, which includes chemotaxis, increased longevity [38], and enhanced production of proinflammatory cytokines (i.e. tumor necrosis factor-alpha, interleukin1, interleukin-6) from monocytes stimulated by lipopolisaccharide.

Another mechanism of beneficial influence of fucoidan on vascular remodeling may be mediated by its influence on endothelial cells, as it was shown that LMWH fucoidan treatment stimulated allografts reendothelialization [14]. Low molecular weight fucoidan enhanced endothelial cell migration [39]. Additionally, as an antithrombotic and proangiogenic factor, fucoidan initiates endothelial cell differentiation and proliferation after vascular injury [40, 45].

This is the first study demonstrating the beneficial effect of oral administration on diminishing vascular remodeling. The oral administration of drugs is especially convenient due to its simplicity. This administration route can also be used in extension therapy for chronic treatment. The oral administration of heparinoids is effective in the prevention of thrombosis in rats [41,47,48]. Our results confirm the effectiveness of the oral route of fucoidan administration in the inhibition of vascular remodeling triggered by immunological stimuli in rat model.

As a result, we present the influence of fucoidan on vascular remodeling in transplant vasculopathy in rat. This is the first report discussing the beneficial effect of fucoidan oral administration on this process, which may have important clinical implications and can lead to better understanding of vascular remodeling.

\section{CONCLUSION}

We demonstrate the inhibitory effect of fucoidan on vascular remodeling in transplant vasculopathy in rat. This is the first report of beneficial effect of fucoidan oral administration on this process, which may have important clinical implications and lead to a better understanding of vascular remodeling. 
List of Abbreviations: BID, bis in die (twice a day); CD45, protein tyrosine phosphatase, receptor type C (PTPRC); DAB, 3,3'-Diaminobenzidine; ED-1, macrophage marker (=CD68); ELISA, enzyme-linked immunosorbent assay; eNOS, endothelial nitric oxide synthase-3; FGF-2, fibroblast growth factor-2; FXa, calf factor X; HBP, heparin-binding-protein; HUVEC, human umbilical vein endothelial cells; IFN gamma, interferon gamma; LMWH, low molecular weight heparin; MSR, macrophage scavenger receptor; NO, nitric oxide; pNA, p-nitroaniline; SDF-1, stromal-derived factor-1; SMCs, smooth muscle cells; TUNEL, TdT-mediated dUTP Nick-End Labeling.

Authors' Contributions: JS and ZG participated in research design. EK, KB, ZG, and GH participated in the writing of the paper. KB and JS participated in the performance of the research; ZG contributed new reagents or analytic tools. JS and EK participated in data analysis.

Acknowledgements and Funding: This work was supported by grants from BASTION, Warsaw Medical University, EU FP7 IDEA, National Science Centre based on decision DEC2013/11/N/NZ4/02288, Polish Scientific Committee and Karolinska Institute, Cost Action CM1 106 (StemChem)-Chemical Approaches to Targeting Drug Resistance in Cancer Stem Cells.

\section{REFERENCES}

1. Libby P, Pober JS: Chronic rejection. Immunity 2001, 14(4):387-97. PubMed PMID: 11336684.

2. Lusis AJ: Atherosclerosis. Nature 2000, 407(6801):233-41. PubMed PMID: 11001066. Pubmed Central PMCID: 2826222.

3. Chizhov AO, Dell A, Morris HR, Haslam SM, McDowell RA, Shashkov AS, et al.: A study of fucoidan from the brown seaweed Chorda filum. Carbohydr Res 1999, 320(1-2):108-19. PubMed PMID: 10515064.

4. Berteau O, Mulloy B: Sulfated fucans, fresh perspectives: structures, functions, and biological properties of sulfated fucans and an overview of enzymes active toward this class of polysaccharide. Glycobiology 2003, 13(6):29R-40R. PubMed PMID: 12626402.

5. Belford DA, Hendry IA, Parish CR: Investigation of the ability of several naturally occurring and synthetic polyanions to bind to and potentiate the biological activity of acidic fibroblast growth factor. J Cell Physiol 1993, 157(1):184-9. PubMed PMID: 7691835.

6. Kim TH, Lee EK, Lee MJ, Kim JH, Yang WS: Fucoidan inhibits activation and receptor binding of transforming growth factor-beta1. Biochem Biophys Res Commun 2013, 432(1):163-8. PubMed PMID: 23348228.

7. Frenette PS, Weiss L: Sulfated glycans induce rapid hematopoietic progenitor cell mobilization: evidence for selectin-dependent and independent mechanisms. Blood 2000, 96(7):2460-8. PubMed PMID: 11001898. 
8. Sweeney EA, Lortat-Jacob H, Priestley GV, Nakamoto B, Papayannopoulou T: Sulfated polysaccharides increase plasma levels of SDF-1 in monkeys and mice: involvement in mobilization of stem/progenitor cells. Blood 2002, 99(1):44-51. PubMed PMID: 11756151.

9. Sweeney EA, Priestley GV, Nakamoto B, Collins RG, Beaudet AL, Papayannopoulou T: Mobilization of stem/progenitor cells by sulfated polysaccharides does not require selectin presence. Proc Natl Acad Sci USA 2000, 97(12):6544-9. PubMed PMID: 10841555. Pubmed Central PMCID: Pmc18653. Epub 2000/06/07. eng.

10. Kanabar V, Hirst SJ, O'Connor BJ, Page CP: Some structural determinants of the antiproliferative effect of heparin-like molecules on human airway smooth muscle. $\mathrm{Br} \mathrm{J}$ Pharmacol 2005, 146(3):370-7. PubMed PMID: 16025136. Pubmed Central PMCID: 1576283.

11. McCaffrey TA, Falcone DJ, Borth W, Brayton CF, Weksler BB: Fucoidan is a nonanticoagulant inhibitor of intimal hyperplasia. Biochem Biophys Res Commun 1992, 184(2):773-81. PubMed PMID: 1315533. Epub 1992/04/30. eng.

12. Logeart D, Prigent-Richard S, Jozefonvicz J, Letourneur D: Fucans, sulfated polysaccharides extracted from brown seaweeds, inhibit vascular smooth muscle cell proliferation. I. Comparison with heparin for antiproliferative activity, binding and internalization. Eur J Cell Biol 1997, 74(4):376-84. PubMed PMID: 9438134.

13. Deux JF, Meddahi-Pelle A, Le Blanche AF, Feldman LJ, Colliec-Jouault S, Bree F, et al.: Low molecular weight fucoidan prevents neointimal hyperplasia in rabbit iliac artery instent restenosis model. Arterioscler Thromb Vasc Biol 2002, 22(10):1604-9. PubMed PMID: 12377737.

14. Freguin-Bouilland C, Alkhatib B, David N, Lallemand F, Henry JP, Godin M, et al.: Low molecular weight fucoidan prevents neointimal hyperplasia after aortic allografting. Transplantation 2007, 83(9):1234-41. PubMed PMID: 17496541.

15. Alkhatib B, Freguin-Bouilland C, Lallemand F, Henry JP, Litzler PY, Marie JP, et al.: Low molecular weight fucan prevents transplant coronaropathy in rat cardiac allograft model. Transpl Immunol 2006, 16(1):14-9. PubMed PMID: 16701171.

16. Grudzinska MK, Kurzejamska E, Bojakowski K, Soin J, Lehmann MH, Reinecke H, et al.: Monocyte chemoattractant protein 1-mediated migration of mesenchymal stem cells is a source of intimal hyperplasia. Arterioscler Thromb Vasc Biol 2013, 33(6):1271-9. PubMed PMID: 23599443.

17. Abe S, Hiramatsu K, Ichikawa O, Kawamoto H, Kasagi T, Miki Y, et al.: Safety evaluation of excessive ingestion of mozuku fucoidan in human. J Food Sci 2013, 78(4):T648-51. PubMed PMID: 23465035. Epub 2013/03/08. eng.

18. Irhimeh MR, Fitton JH, Lowenthal RM: Fucoidan ingestion increases the expression of CXCR4 on human CD34+ cells. Exp Hematol 2007, 35(6):989-94. PubMed PMID: 17533053. 
19. Myers SP, O'Connor J, Fitton JH, Brooks L, Rolfe M, Connellan P, et al.: A combined phase I and II open label study on the effects of a seaweed extract nutrient complex on osteoarthritis. Biologics 2010;4:33-44. PubMed PMID: 20376172. Pubmed Central PMCID: 2846142.

20. Bojakowski K, Religa P, Bojakowska M, Hedin U, Gaciong Z, Thyberg J: Arteriosclerosis in rat aortic allografts: early changes in endothelial integrity and smooth muscle phenotype. Transplantation 2000, 70(1):65-72. PubMed PMID: 10919577.

21. Cui W, Zheng Y, Zhang Q, Wang J, Wang L, Yang W, et al.: Low-molecular-weight fucoidan protects endothelial function and ameliorates basal hypertension in diabetic GotoKakizaki rats. Lab Invest. 2014 Apr;94(4):382-93. PubMed PMID: 24614196. Epub 2014/03/13. eng.

22. Forte A, Della Corte A, De Feo M, Cerasuolo F, Cipollaro M: Role of myofibroblasts in vascular remodelling: focus on restenosis and aneurysm. Cardiovasc Res 2010, 88(3):395405. PubMed PMID: 20621923.

23. Hlawaty H, Suffee N, Sutton A, Oudar O, Haddad O, Ollivier V, et al.: Low molecular weight fucoidan prevents intimal hyperplasia in rat injured thoracic aorta through the modulation of matrix metalloproteinase-2 expression. Biochem Pharmacol 2011, 81(2):23343. PubMed PMID: 20887714. Epub 2010/10/05. eng.

24. McCaffrey TA, Falcone DJ, Vicente D, Du B, Consigli S, Borth W: Protection of transforming growth factor-beta 1 activity by heparin and fucoidan. J Cell Physiol 1994, 159(1):51-9. PubMed PMID: 7511146.

25. Religa P, Kazi M, Thyberg J, Gaciong Z, Swedenborg J, Hedin U: Fucoidan inhibits smooth muscle cell proliferation and reduces mitogen-activated protein kinase activity. Eur J Vasc Endovasc Surg 2000, 20(5):419-26. PubMed PMID: 11112459.

26. Savani RC, Wang C, Yang B, Zhang S, Kinsella MG, Wight TN, et al.: Migration of bovine aortic smooth muscle cells after wounding injury. The role of hyaluronan and RHAMM. J Clin Invest 1995, 95(3):1158-68. PubMed PMID: 7533785. Pubmed Central PMCID: 441453.

27. Greenberg RS, Bernstein AM, Benezra M, Gelman IH, Taliana L, Masur SK: FAKdependent regulation of myofibroblast differentiation. FASEB J 2006, 20(7):1006-8. PubMed PMID: 16585062.

28. Kazi M, Lundmark K, Religa P, Gouda I, Larm O, Ray A, et al.: Inhibition of rat smooth muscle cell adhesion and proliferation by non-anticoagulant heparins. J Cell Physiol 2002,193(3):365-72. PubMed PMID: 12384988.

29. Welt FG, Tso C, Edelman ER, Kjelsberg MA, Paolini JF, Seifert P, et al.: Leukocyte recruitment and expression of chemokines following different forms of vascular injury. Vascular medicine 2003, 8(1):1-7. PubMed PMID: 12866605. 
30. Tseng CN, Chang YT, Lengquist M, Kronqvist M, Hedin U, Eriksson EE: Platelet adhesion on endothelium early after vein grafting mediates leukocyte recruitment and intimal hyperplasia in a murine model. Thrombosis and haemostasis, 113(4):813-25. PubMed PMID: 25518998.

31. Preobrazhenskaya ME, Berman AE, Mikhailov VI, Ushakova NA, Mazurov AV, Semenov AV, et al.: Fucoidan inhibits leukocyte recruitment in a model peritoneal inflammation in rat and blocks interaction of P-selectin with its carbohydrate ligand. Biochem Mol Biol Int. 1997, 43(2):443-51. PubMed PMID: WOS:000073190900023. English.

32. Sakihama H, Masunaga T, Yamashita K, Hashimoto T, Inobe M, Todo S, et al.: Stromal cell-derived factor-1 and CXCR4 interaction is critical for development of transplant arteriosclerosis. Circulation 2004, 110(18):2924-30. PubMed PMID: 15505104.

33. Religa P, Grudzinska MK, Bojakowski K, Soin J, Nozynski J, Zakliczynski M, et al.: Hostderived smooth muscle cells accumulate in cardiac allografts: role of inflammation and monocyte chemoattractant protein 1. PLoS One 2009, 4(1):e4187. PubMed PMID: 19142231. Pubmed Central PMCID: 2615209.

34. Husain T, Abbott CR, Scott DJ, Gough MJ: Macrophage accumulation within the cap of carotid atherosclerotic plaques is associated with the onset of cerebral ischemic events. J Vasc Surg 1999, 30(2):269-76. PubMed PMID: 10436446.

35. Nakamura T, Suzuki H, Wada Y, Kodama T, Doi T: Fucoidan induces nitric oxide production via p38 mitogen-activated protein kinase and NF-kappaB-dependent signaling pathways through macrophage scavenger receptors. Biochem Biophys Res Commun 2006, 343(1):286-94. PubMed PMID: 16540084.

36. Schreyer SA, Peschon JJ, LeBoeuf RC: Accelerated atherosclerosis in mice lacking tumor necrosis factor receptor p55. J Biol Chem 1996, 271(42):26174-8. PubMed PMID: 8824264.

37. Santiago-Garcia J, Kodama T, Pitas RE: The class A scavenger receptor binds to proteoglycans and mediates adhesion of macrophages to the extracellular matrix. J Biol Chem 2003, 278(9):6942-6. PubMed PMID: 12488451.

38. Pereira HA: CAP37, a neutrophil-derived multifunctional inflammatory mediator. J Leukoc Biol 1995, 57(6):805-12. PubMed PMID: 7790760.

39. Lake AC, Vassy R, Di Benedetto M, Lavigne D, Le Visage C, Perret GY, et al.: Low molecular weight fucoidan increases VEGF165-induced endothelial cell migration by enhancing VEGF165 binding to VEGFR-2 and NRP1. J Biol Chem 2006, 281(49):3784452. PubMed PMID: 17028197.

40. Chabut D, Fischer AM, Colliec-Jouault S, Laurendeau I, Matou S, Le Bonniec B, et al.: Low molecular weight fucoidan and heparin enhance the basic fibroblast growth factor-induced tube formation of endothelial cells through heparan sulfate-dependent alpha6 overexpression. Mol Pharmacol 2003, 64(3):696-702. PubMed PMID: 12920206. 
41. Hiebert LM, Wice SM, Ping T: Tissue distribution of the low molecular weight heparin, tinzaparin, following administration to rats by the oral route. Biomed Pharmacother 2004, 58(6-7):372-80. PubMed PMID: 15271419.

42. Akramiene D, Kondrotas A, Didziapetriene J, Kevelaitis E: Effects of $\beta$-glucans on the immune system. Med (Kaunas) 2007, 43(8):597-606.

43. Chan GCF, Chan WKS, DMY: The effects of $\beta$-glucan on human immune and cancer cells. J Haematol Oncol 2009, 2:25. https://doi.org/10.1186/1756-8722-2-25.

44. Babal K, Gionta RA: Seafood Sense. [www.ReadHowYouWant.com]

45. Li B, Lu F, Wei X, Zhao R: Fucoidan: structure and bioactivity. Molecules 2008, 13(8):1671-95.

46. Ananthaseshan S, Grudzinska MK, Bojakowski K, Kurzejamska E, Gaciong Z, SoderbergNaucler C, Religa P: Locally Transplanted CD34+ Bone Marrow-Derived Cells Contribute to Vascular Healing After Vascular Injury, Transplant Proc 2017, 49(6):1467-1476. DOI: https://doi.org/10.1016/j.transproceed.2017.01.081.

47. Yokota T, Nomura K, Nagashima M, Kamimura N: Fucoidan alleviates high-fat dietinduced dyslipidemia and atherosclerosis in $\mathrm{ApoE}(\mathrm{shl})$ mice deficient in apolipoprotein $\mathrm{E}$ expression. J Nutr Biochem 2016, 32:46-54. https://doi.org/10.1016/j.jnutbio.2016.01.011. Epub 2016;

48. Kim MJ, Jeon J, Lee JS: Fucoidan prevents high-fat diet-induced obesity in animals by suppression of fat accumulation. Phytother Res 2014, 28(1):137-43. DOI: https://doi.org/10.1002/ptr.4965. 